\title{
SYENITE-GNEISS (LEOPARD ROCK) FROM THE . APATITE REGION OF OTTAWA COUNTY, CANADA*
}

\author{
BY C. H. GORDON \\ (Presented before the Society August 28, 1895)
}

\section{CONTENTS}

Page

General description of the region $\ldots \ldots \ldots \ldots \ldots \ldots \ldots \ldots \ldots \ldots \ldots, 96$

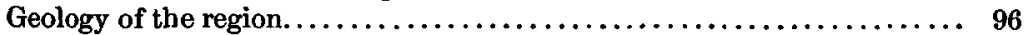

Character and classification of the rocks................... 96

Lithological characters $\ldots \ldots \ldots \ldots \ldots \ldots \ldots \ldots \ldots \ldots \ldots \ldots, 98$

High Rock district..................................... 98

General description $\ldots \ldots \ldots \ldots \ldots \ldots \ldots \ldots \ldots \ldots \ldots \ldots \ldots \ldots, 98$

Geological structure............................... 99

Subdivisions of the syenite-gneiss. ........................... 99

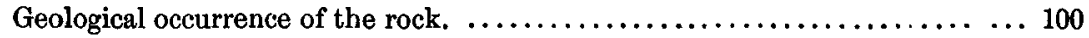

Megascopical characters.................................... 103

Coarse syenite-gneiss................................. 103

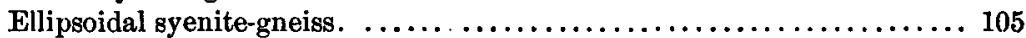

Streaked syenite-gneiss. . . . . . . . . . . . . . . . . . . . . . .

Microscopical description................................. 107

Coarse syenite-gneiss. ............................. 107

Ellipsoidal syenite-gneiss or leopard rock $\ldots \ldots \ldots \ldots \ldots \ldots \ldots \ldots \ldots \ldots 114$

Streaked syenite-gneiss.................................. 117

Character and relations of the rocks............................ 119

Nomenclature........................................... 120

Origin of the ellipsoidal structure.............................. 123

General hypotheses.................................... 123

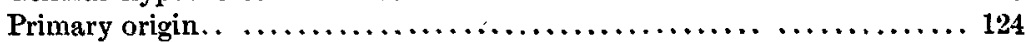

Differentiation of the coarse syenite $\ldots \ldots \ldots \ldots \ldots \ldots \ldots \ldots \ldots \ldots, 124$

Differentiation of the ellipsoidal rock................... 125

*Condensation of thesis presented for degree of Doctor of Philosophy, University of Chicago, June $13,1895$.

The author is indebted to Dr A. R. C. Selwyn and his associates on the Canadian Geological Survey and to Mr A. P. Twidale, superintendent of the High Rock phosphate mine, for numerous courtesies and farors. The analyses were made by Professor William Hoskins, of the Chicago Academy of Sciences. Especial acknowledgments are made to Professor J. P. Iddings for his keen, critical analysis and painstaking assistance. Without his aid the paper would lack much of any value it may possess. 
Page

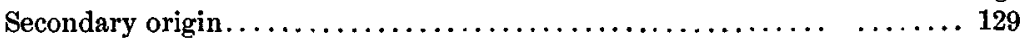

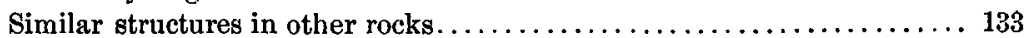

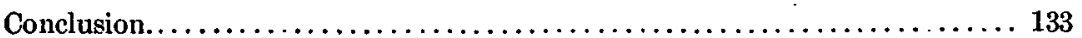

\section{INTRODUCTION.}

GENER.AL DESCRIPTION OF THE REGION.

The apatite region of Ottawa county comprises the area included between the lower portions of the Du Lievre and Gatineau rivers. The chief mining districts occur in Portland and Templeton townships, but deposits of greater or less extent are found over nearly the whole of the area.

The region lies upon the southern flank of the Laurentian axis, and is characterized in large part by a somewhat rugged topography. For some distance north of the Ottawa river, the surface is comparatively level, but this feature gradually gives place to hills which rise to a height of from 500 to 700 feet above the level of the adjacent rivers. The hills are covered with a meager soil, and the forest growth, originally limited, has been largely swept away by fires. The region is drained chiefly by the two rivers mentioned above, which flow southward into the Ottawa river. These streams are of considerable size, have swift currents, and rapids frequently occur. Waterfalls also constitute a picturesque feature of these streams. High falls, on the Du Lievre, has a descent of about 100 feet.

The country between the streams is dotted with numerous lakes, which drain through small streams with tortuous courses into the Du Lievre or the Gatineau, or southward into the Ottawa. These lakes are extremely irregular in shape, with sharply sinuous shorelines, and often contain small islands.

\section{QEOLOGY OF THE REGION.}

Character and classification of the rocks. - In order to arrive at a proper understanding of the nature and occurrence of the ellipsoidal syenitegneiss or leopard rock, it is necessary to introduce a brief description of the geology of the region. The facts upon which this description is based have been obtained chiefly from the reports of the Canadian Geological and Natural History Survey.*

* We are indebted chiefly to the reports of Vennor and Harrington, and to Professor F. D. Adams' account of the typical Laurentian area in the Journal of Geology, vol. i, No.4, 1893, pp. 325-340. The map here given was taken from that accompanying H. G. Vennor's report in the Annual Report for 1878 . 
In its geological structure the region consists of alternating bands of gneiss, crystalline limestones and pyroxenic rocks, in which are interstratified a number of zones of quartzites, rust-colored rock or fahlbands, and several horizons of magnetic iron ore. These rocks all belong to the Grenville series, the uppermost of the two main divisions into which the Laurentian system is now quite generally divided.

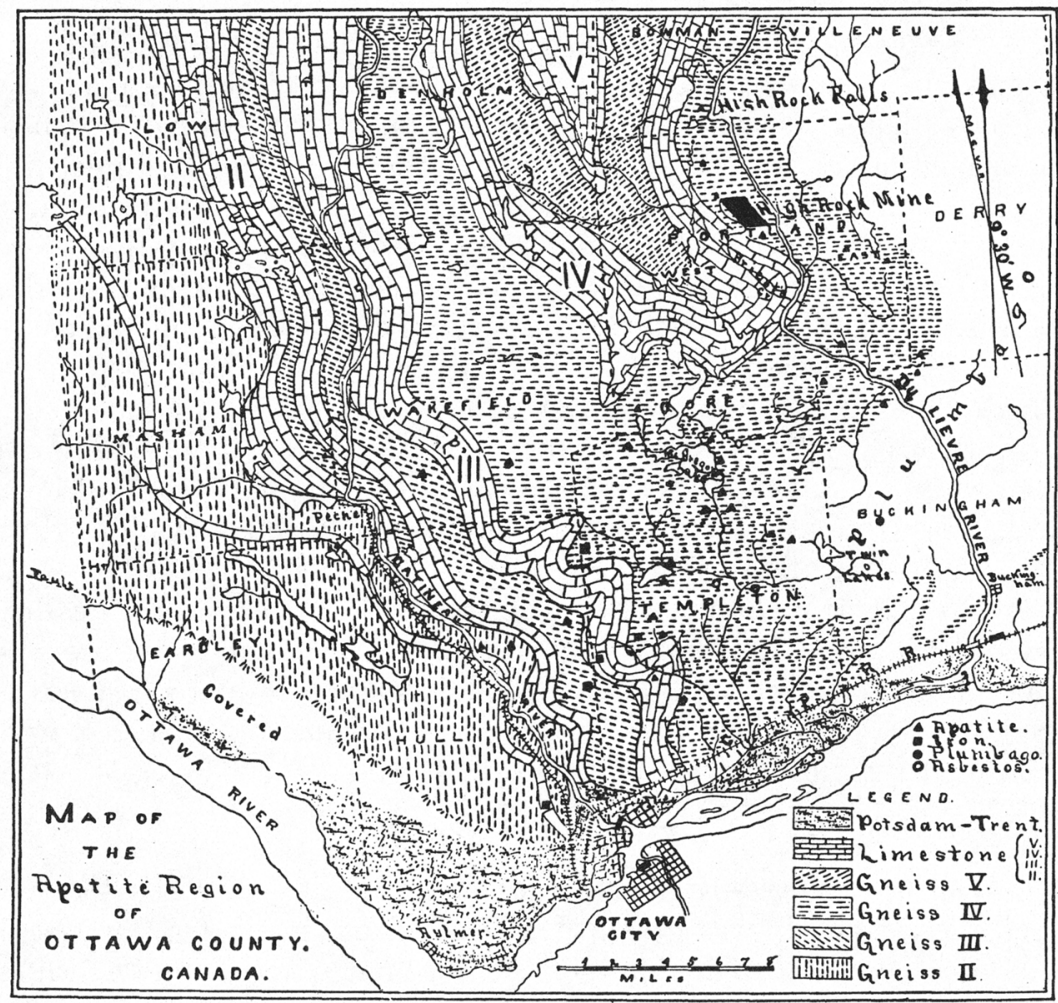

FIGURE I.-The Apatite Region of Ottawa County, Canada.

The Grenville series includes rocks of very different petrographical development and of great variability in mineralogic composition. "In it are found all the mineral deposits of economic value-apatite, iron ore, asbestos, etcetera-which occur in the Laurentian."*

Apatite is found quite generally throughout the series, but the principal workable deposits occur in a belt (see IV, figure 1) of rust-colored 
gneisses and pyroxenic and feldspar rocks above the Gatineau limestone band (III).

As shown on the map, in the region between the Gatineau and $\mathrm{Du}$ Lievre rivers the rocks are arranged in the form of a great synclinal, with Big lake marking approximately the location of the axis. On passing eastward from the west line of Ottawa county, therefore, we pass over the different belts in ascending order until we reach the east line of Denham township.

Lithological characters.-The gneisses interstratified with the limestones vary much in character, but the predominating variety consists of a more or less reddish orthoclase and grayish white quartz with little or no mica and sometimes with garnets. It is usually coarse or granitoid in structure and the bedding often obscure, though in places it contains numerous beds or layers of quartzite from half an inch to a foot in thickness, which render the strike of the rock plainly visible. In some cases the mica is abundant and the gneiss then assumes a marked foliated character. The micaceous gneisses are sometimes garnetiferous and occasionally exhibit the texture of the so-called augen-gneiss.

Quartzites of considerable thickness occur now and then. They are often white and glassy and in places contain a little orthoclase. These strata are frequently traversed by dolerite dikes, some of which are of considerable thickness.

The pyroxenic rocks associated with the apatite, and by Hunt* called pyroxenites, vary considerably in their characters. Sometimes they consist almost exclusively of pyroxene, though commonly quartz and orthoclase are present. Mica and apatite are of frequent occurrence, and occasionally minute garnets may be seen.

\section{HIGH ROCK DISTRICT.}

General description.-High Rock mine, the locality at which the material for this study was obtained, is located on a series of connected hills situated on the right bank of the $\mathrm{Du}$ Lievre river, about 21 miles above Buckingham. The openings cover in all about 600 acres on the tops of the hills which extend to a height of 700 feet above the level of the river. They are reached from the river by a tramway two miles long following the natural slope of the hill. The series of hills trend in a direction south $30^{\circ}$ east (magnetic). The openings are all in one wide belt of pyroxenic rock having a strike in the same direction. The main opening is number 11, the entrance to which is on the west side of the hill about 180 feet below the summit. The vein in which this pit is opened has been worked at several places along the side of the hill. Other veins

* Geology of Canada, 1866, p. 185. Chemical and Geological Essays, p. 208. 
parallel with this occur along the top of the ridge and have been worked at various points. In all some 35 or 40 openings have been made on this property.

Geological structure.-The hills are made up of quartzite, pyroxenite, and gneiss in belts whose direction corresponds with that of the ridge. The apatite occurs in veins or pockets in the pyroxenite. The quartzite occurs in beds standing in a nearly vertical position and with strike parallel to the general direction of the ridge.

The pyroxenite is not distinctly banded, though occasionally parallel lines, which have sometimes been taken to represent lines of stratification, can be traced through it.

Stratified and massive gneisses are reported $*$ as often seen bordering the hills in the apatite region, but they were not made the subject of study at High Rock.

The rocks all dip at high angles (nearly vertical), and are cut in various directions by small dikes.

At several places on the hill bosses of feldspar rock appear protruding through the quartzites and pyroxenites, and expanding at the surface. An instance of this is seen near the summit in front of the office. 'The feldspar is coarsely crystallized, of a lilac color, and is associated with a considerable amount of augite.

In most of the openings, the apatite is associated with a reticulated feldspar rock, consisting of lumps of coarse feldspar (and a variable amount of quartz), separated from each other by thin anastomosing layers of green augite and a small amount of fine grained feldspar. This rock, which it is the chief purpose of this paper to discuss, is closely associated with the coarse feldspathic rock above mentioned, and evidently belongs to the same rock body. In places it has a distinctly striped gneissoid appearance. In general it is composed chiefly of an alkali feldspar and augite, with a comparatively small amount of quartz, thus presenting the mineral composition of an augite-syenite. As the rock in all its phases shows more or less evidence of dynamic action, it is properly to be regarded as a gneiss, and may therefore be designated as an augite-syenitegneiss.

\section{Subdivisions of the Syenite-Gneiss.}

The term syenite-gneiss is here used to include a peculiar assemblage of rocks occurring at High Rock and neighboring mines, among which is the so-called "leopard rock " or "concretionary veinstone" of the Cana dian geologists. The rock presents three distinct phases, which for con- 
venience may be treated separately, though they belong to the same rock mass and grade into each other almost imperceptibly. They are-

Coarse grained syenite-gneiss.

Ellipsoidal syenite-gneiss (leopard rock).

Streaked syenite-gneiss.

\section{Geological Occurrence of the Rock.}

The rock here described occurs in the form of dikes, sometimes cutting across the strike of the inclosing rocks and sometimes intercalated in them. In one form or another it is found at nearly all the apatite openings examined.

At the top of the hills at High Rock, about 20 rods southeast of the office, the exposed surface consists of a belt of pyroxenite inclosed in

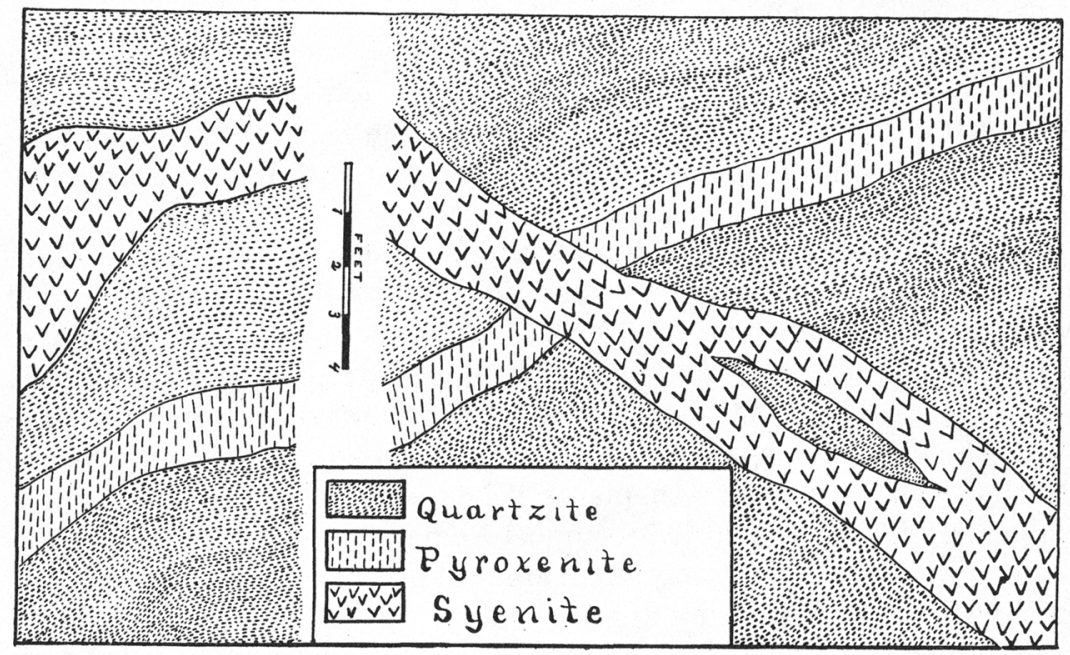

FIGURE 2-Dike of coarse Syenite-gneiss cutting Quartzite and Pyroxenite.

A mass of the quartzite is inclosed in the syenite. The pyroxenite appears as a dike intercalated in the quartzite.

quartzite, with a strike of south $30^{\circ}$ east (magnetic). At one point there is a slight linear depression covered with soil transverse to the strike of the rock, which evidently represents a fault. On the south side of this depression the beds of quartzite and intercalated pyroxenite have been shifted about two feet to the east. On the north side both pyroxenite and quartzite are cut by a dike of coarse grained syenite in a direction south $20^{\circ}$ east (magnetic). After passing the supposed fault-line the dike 
bears easterly, parallel with the bedding of the quartzite. These relations are shown in the accompanying sketch.

The dike is about a foot wide, and consists chiefly of coarsely crystallized dark grayish or purplish feldspar (microcline), with grains and aggregates of augite and occasional patches of quartz. The grain is quite uniform, except for a thickness of about one centimeter next the walls, which is of a finer grain (number 132). At one point a fragment of the quartzite is inclosed in the syenite. At an apatite opening southeast of

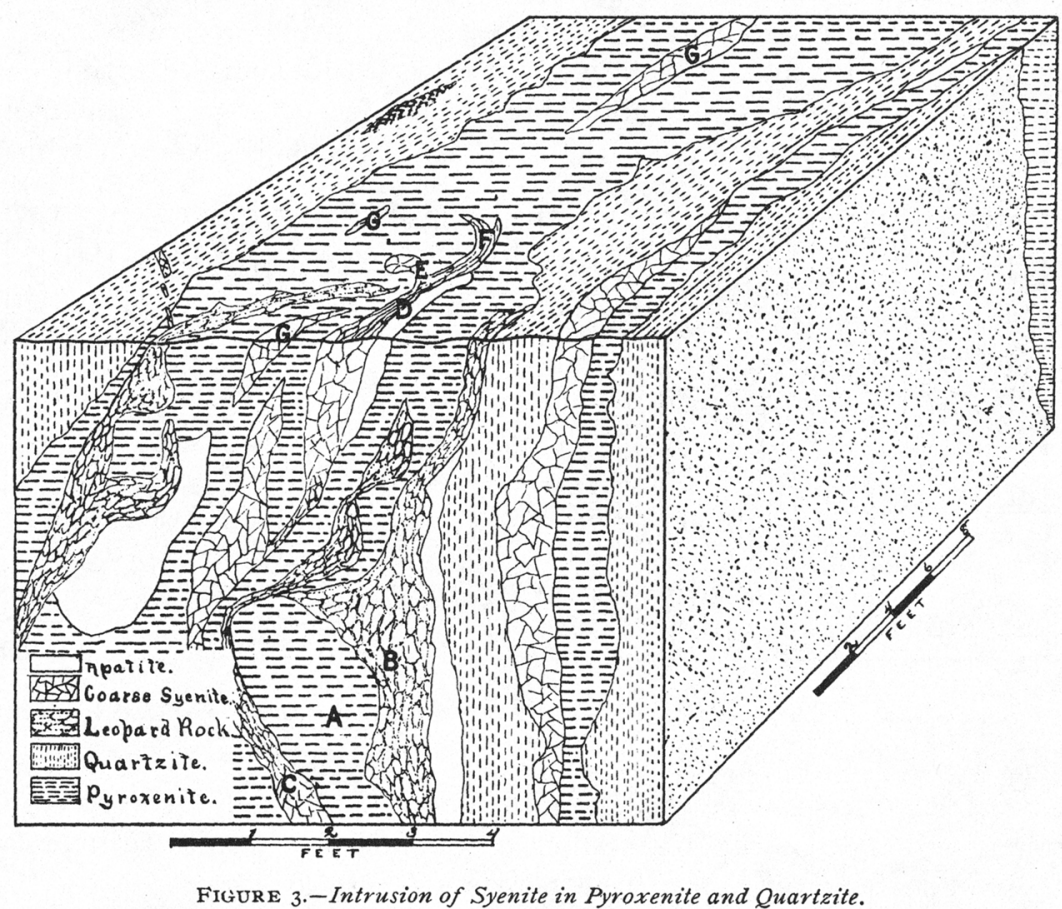

The locality is at an apatite pit on the hill, about 30 rods southeast of the office. The front face indicates the relations as shown in the wall of the pit, while the top represents the surface exposure.

this, in the line of strike, the syenite is seen cutting the pyroxenite, as shown in relief in figure 3 . The pyroxenite has been broken up, and the different parts intricately involved in the intrusive mass. At this exposure the different phases shown by the syenitic rock are seen grading into each other. In some parts the intruding rock is of a coarse grained character, while in other places it shows the ellipsoidal structure, grading finally into the striped gneissoid rock. At one point in the wall of the pit a large mass of the pyroxenite ( $A$, figure 3$)$ is in contact on one 
side with the coarse grained variety $(C)$, while on the other $(B)$ there is an excellent development of the ellipsoidal structure, with the longer axes of the ellipsoids arranged approximately parallel to the adjacent boundaries of the pyroxenite. The latter at the point marked $A$ shows an interlamination with apatite such as has. been frequently noted in the apatite regions.*

The surface exposure shows one branch $(D-F)$ of the syenite intrusion narrowed and curving. At $D$ the ellipsoids have become so flattened and attenuated that in transverse section they appear as parallel bands of reddish white feldspar alternating with thin stripes of augite. At $F$, however, the ellipsoidal structure again appears with sharp little trenches surrounding the feldspathic ellipsoids, due to the weathering of the interstitial augite layers (number 139). At $E$ a branch is given off, which

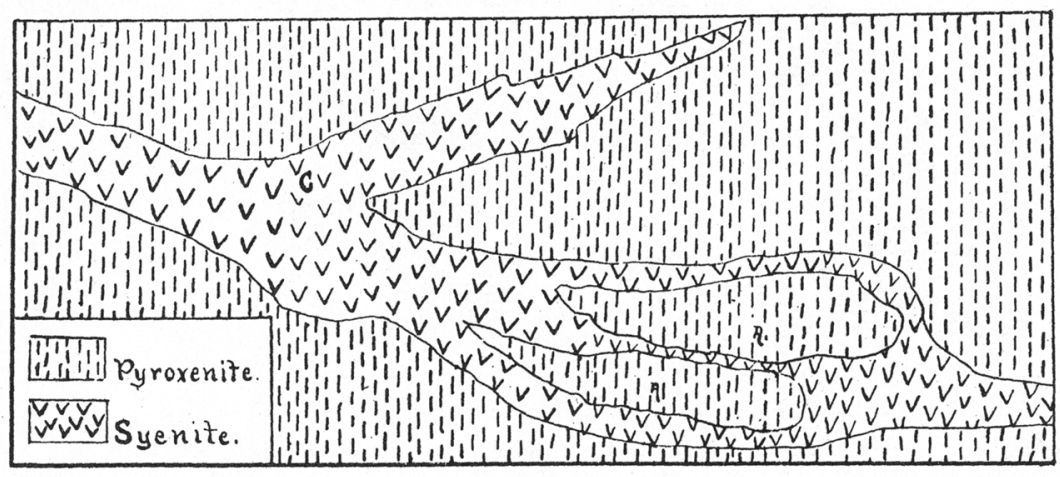

Frgure 4.-Dike of coarse Syenite-gneiss cutting Pyroxenite and inclosing Portions $(A)$ of the latter.

consists of the coarse grained syenite rock, with no indication of ellipsoidal or banded structure. Other portions of the syenite rock make their appearance at the surface here and there as lenses $(G)$ in the pyroxenite.

On the brow of the hill above pit number 11 the pyroxenite is cut by a dike of syenite, a foot or more wide, extending from north $10^{\circ}$ west to south $10^{\circ}$ east.

The dike dips into the hill at a slight angle with the vertical, and at one point gives off a branch $(C)$, which soon wedges out in the pyroxenite. Fragments of the pyroxenite are inclosed in the syenite, as shown

*W. Boyd Dawkins: Proc. Manchester Geol. Soc., 1884.

Note. -The rocks referred to here are represented in the collection by the following numbers: $A=$ numbers 109,110, pyroxenite. $D=$ number 139 , ellipsoidal gneiss, weathered. $B=$ number 138 , ellipsoidal syenite-gneiss. $\quad E=$ “ 140 , streaked syenite-gneiss.

$C=$ " 133, coarse syenite-gneiss. 
at $A$. The intruded rock (number 164) is medium to coarse grained, but shows a finer texture in the narrow passage between the inclosed masses of pyroxenite.

At number 11 opening the ellipsoidal or leopard rock occurs in abundance, and constitutes a large part of the wall in places. At one point in the face of the wall a crystal of apatite, six inches or more in diameter, was seen inclosed in the leopard rock, with the ellipsoidal masses disposed in a concentric manner about it. Examples showing the same relations between more or less crushed apatite and the leopard rock were frequent in the refuse of the dumps, but the presence of crystallographic form is exceptional.

At various places on the hill dome-like masses of the coarse grained syenite rock appear as local enlargements of the dike. One of these near the office shows fragments of pyroxenite scattered through the intrusive mass.

These observations, which may be duplicated many times in the vicinity, are sufficient to demonstrate-

1. That the coarse grained syenitic rock, the leopard rock and the streaked gneiss belong to the same rock-body ; and,

2. That this body represents an intrusion of syenite later than that of the pyroxenite.

An interesting feature of these syenitic rocks is their remarkably fresh condition. This appearance, which is prominently characteristic of the rock in the hand specimen, is also shown in the thin section, where very little evidence of decomposition is to be observed. Epidote and chlorite, generally common as decomposition products, are rare in these rocks.

\section{Megascopical Characters.}

\section{COARSE SYENITE-GNEISS.}

The first of the syenite-gneisses consists of a very coarse grained mixture of microcline and monoclinic pyroxene chiefly, with a variable amount of quartz. The rock is divided into irregular angular blocks, the largest being one or two inches across, separated by thin anastomosing sheets of granular feldspar, augite and quartz. These interstitial areas are sometimes thick enough to be readily traceable in the hand specimen. Many, however, are scarcely or not at all recognizable megascopically, but are brought out with distinctness under the microscope.

The microcline is of a dark gray, often purplish color, crystallized in large individuals, frequently from one to two inches in diameter. The larger cleavage faces show a slight undulatory surface, with variable reflection and bright pearly sheen. 
104 C. H. GORDON-SYENITE-GNEISS (LEOPARD ROCK) FROM CANADA.

An analysis of the microline by William Hoskins, of Chicago, gave the following results :

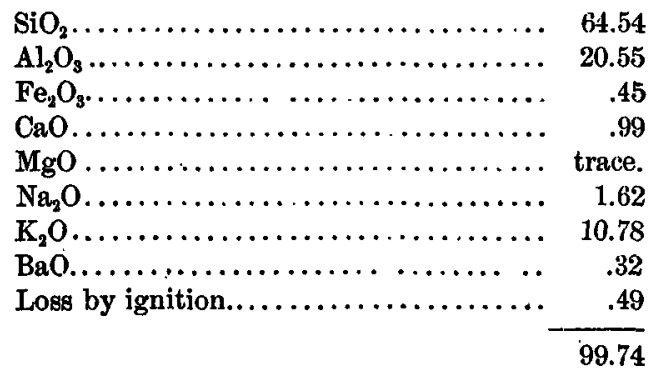

The pyroxene is of a dark green color, and occurs both in well formed prisms and as irregular aggregates of considerable size. The prisms are long and slender, and occur chiefly inclosed in the microcline, though they are associated sometimes with the quartz in the granular areas. In the latter case, however, they are usually shorter and sometimes show evidence of breaking. 'The prisms are elongated in the direction of the vertical axis and have a very nearly equal development of the faces $\infty P \frac{1}{\infty}(100), \infty P^{\circ} \infty(010), P(110)$. The pyroxene is more abundant in places, forming aggregates, inclosing a varying amount of feldspar, pyrites, and titanite. In these areas the pyroxene is coarsely crystallized and of a lighter green than the idiomorphic individuals.

An analysis of the crystals inclosed in the microcline by $\mathrm{Mr}$ Hoskins gave the following results:

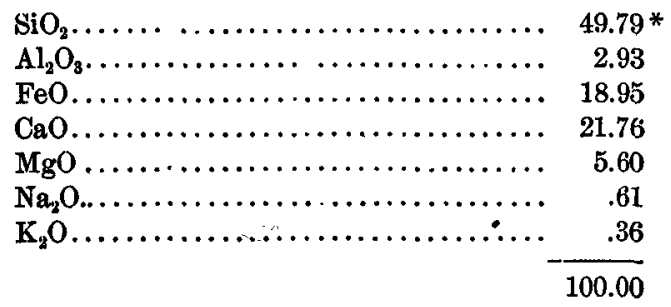

'The analysis shows a high percentage of iron, while alumina and magnesium are correspondingly low. Taken in connection with its physical characters, the analysis seems to indicate an augite closely allied to diallage.

Quartz occurs chiefly in nests and strings, associated with the interstitial granular areas. Titanite is present as grains disseminated through the rock, but is more abundant along the granular areas. A fine grained 
form of this variety is represented in the collection by two specimens (numbers 128, 129), which are quite uniformly granular and without a distinct gneissic structure. The chief constituents, feldspar and augite, are more or less uniformly distributed.

\section{ELLIPSOIDAL SYENITE-GNEISS.}

In the second phase the rock consists of irregularly ellipsoidal or ovoid masses of feldspar, with more or less quartz, separated by narrow anastomosing partitions of green interstitial material, in which there is sometimes observed a slight schistosity parallel to the surface of the masses they inclose. This is sometimes apparent also in the tendency of the rock to cleave at the contact between the ovoid lumps and the interstitial material.

The ellipsoidal masses are usually more or less elongated and arranged uniformly, with the longer axes lying in the same direction. They are of all sizes up to two or three inches in diameter in cross-section, and several inches long. The grain of the feldspathic lumps is coarse in the more spheroidal forms, but becomes finer as the masses become more and more flattened and elongated. They are composed chiefly of feldspar, with a varying amount of quartz and disseminated grains of titanite, angite and apatite. Larger grains of feldspar often appear in the more flattened forms, inclosed in the finer grained mixture. The interstitial material is of finer texture than these ellipsoidal masses, and seems to be composed chiefly of pyroxene, along with finely granular feldspar and some quartz. The interstitial material sometimes has the appearance of two layers of pyroxene separated by a thin light colored lamina feldspathic in character. In many cases these are seen to represent the wedging out of the ellipsoidal feldspathic masses. Often the thin seam of feldspathic material between two adjoining ellipsoids is found to be directly connected with the small masses of feldspar occupying the angular space between three or more ellipsoids. Sometimes the lumps are flattened to thin lenticular or disk-like forms, which may be bent or folded so as to partially enwrap or inclose adjoining lumps. As these flattened lumps become thin they wrap about the larger ellipsoids, so that when the rock breaks across them the constituents appear to have a concentric arrangement. In some cases, however, the concentric arrangement could not be traced directly into connection with the flattening of the feldspathic masses. The interstitial bands are composed chiefly of dark green pyroxene, in grains often elongated parallel to the vertical axis, along with more or less finely granular feldspar. The pyroxene grains often lie with their longer axes transverse to the pyroxene band, with their ends projecting into the feldspathic areas, thus presenting somewhat 
the appearance of a radiate structure. Usually a thin layer of the feldspar adjoining the pyroxene bands is finer grained than the main part of the lump, but in some cases one or more large grains of microcline will appear to lie directly against the. pyroxene band. On close inspection, however, they will be found to be separated by a very thin layer of fine grained feldspar. A mass of the rock will sometimes show a thin seam of the light coloréd constituent cutting across both pyroxene layers and feldspathic ellipsoids. In may be traced across the latter by its lighter color and finer grain. In specimen $150 \mathrm{a}$ seam of this character cuts entirely through the block, and apparently represents a fracture which has been recemented by subsequent crystallization.

The interstitial filling weathers more readily than the ovoid masses, leaving sharp little trenches surrounding these on exposed surfaces.

Beginning with a somewhat flattened ellipsoidal form, the feldspathic masses become more and more flattened in one direction and extended in a direction normal to it. With this flattening of the ellipsoids, the pyroxene shells become thinner.and arrange themselves more and more in parallel bands until the ellipsoidal structure is more or less completely lost, and in its place there occurs a striped gneissoid rock constituting the third phase. On cross-fracture the pyroxene layers of the latter are seen to coalesce, clearly indicating its relationship to the ellipsoidal rock. Where the rock incloses large crystals or masses of apatite the ellipsoidal lumps arrange themselves more or less concentrically about the inclosure, a feature which is characteristic also of the bands of pyroxene and feldspar in the succeeding phase. 'This is well shown in specimens $137,146,148,154$ and 158.

\section{STREAKED SYENITE-GNEISS.}

As the ovoid masses become more flattened and disk-like the augite layers arrange themselves in parallel bands, alternating with the thicker feldspathic layers. Moreover, there is a marked diminution in the size of the grains, while quartz becomes relatively more abundant. Here and there areas appear which are coarser grained, and in these the pyroxene is less abundant, and is disseminated in grains and small masses instead of being aggregated into layers. There is also observed occasionally in the fine grained gneissoid rock large grains of feldspar, which sometimes inclose grains of pyroxene. The masses of apatite inclosed in the rock vary in size from a few inches to a foot or more across, and around them the bands of pyrnxene and feldspar curve concentrically. The apatite is crushed in part or wholly to a granular, saccharoidal condition. Number 145 shows a portion of such an apatite mass in connection with the adjoining rock. The latter is rather fine grained and is striped with 
pyroxene and feldspar for a space of 10 centimeters from the apatite, beyond which it is coarser grained and without the streaks of augite. In this part the pyroxene is much diminished in amount and occurs only in small, scattering aggregates and grains. Immediately next to the apatite is a layer of feldspar, from $\frac{1}{2}$ to 1 centimeter thick, and much coarser in grain than the succeeding bands. Moreover, the apatite mass is intersected by several thin veins of feldspar and quartz, continuous with that of the surrounding layer. These seams vary in width from 2 millimeters to 5 millimeters, and vary proportionally in the size of grain. At one point a grain of feldspar occupies the full width of the seam. The apatite is granulated on the outer surface of the mass, while the remaining portion is irregularly fissured and broken, though not completely crushed.

In number 155 the layers are sharply plicated, and the augite and feldspathic constituents intermingle to a greater extent than in those with straight layers, thus partially obscuring the banding.

\section{Microscopical Description.}

COARSE SYENITE-GNEISS.

Specimen number 127 (129) consists of coarsely crystallized microcline and a monoclinic pyroxene, with quartz, titanite, apatite and pyrite as accessory constituents. Occasionally a small prism of tourmaline is observed.

The microcline is of a dark gray color and occurs in large grains inclosing numerous well formed prisms of augite, usually long and slender.

The rock is intersected in various directions by granular bands which separate the mass into angular lumps of various sizes. These interstitial bands are usually thin, but become somewhat thicker in places, and consist chiefly of finely granular feldspar, quartz and augite. The quartz appears usually in connection with these granular bands, sometimes in aggregates of considerable size. These interstitial seams, therefore, constitute a rather obscure network of fine grained feldspar, pyroxene and quartz, inclosing various masses of coarse microcline and augite. The augite in the quartz areas occurs both as grains and prisms. The latter, however, are usually shorter than those inclosed in the microcline, and present less well defined crystallographic outlines. Sometimes two short prisms of the same size may be seen lying end to end, but not quite in the same straight line. The idiomorphic individuals are elongated in the direction of the vertical axis, and show a very nearly equal development of the faces $\infty P \frac{1}{\infty}(100), \infty P^{\prime} \infty(010), P(110)$.

Section 129 , cut transverse to the granular band seen in the hand speci- 
men, shows this area to be made up of small angular and rounded grains of microcline, between which in places there is a small amount of feldspar similar to that forming the microperthetic intergrowth observed in the large microcline grains, and which is probably albite. Quartz appears in irregular elongated grains here and there along the granular areas. It has crystallized sharply against the adjoining constituents, fitting closely into their sinuous outlines. Some grains are long and irregular in shape, while others which appear similar are resolved in polarized light into two or more grains having slightly different orientations. Rows of fluid

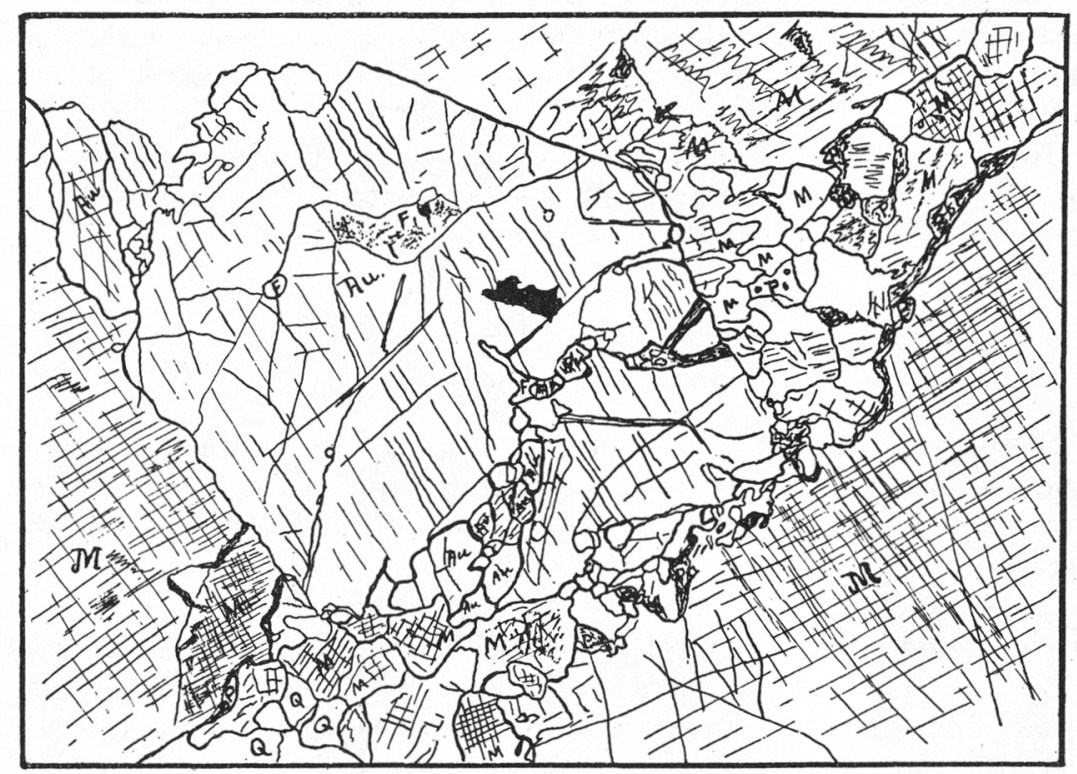

FIGURE 5.-Section Transverse to granular Bands in the coarse Syenite-gneiss.

Showing augite crystal broken in the portion projecting into the granular band. $A u=$ augite ; $M=$ microcline ; $P=$ plagioclase $Q=$ quartz $; F=$ feldspar.

inclusions frequently extend uninterruptedly from one quartz grain to another, while in a few instances they were observed in direct continuity with similar lines of inclusions in the adjoining microcline plates.

The large microcline and augite grains, which constitute the larger part of the section, are traversed in places by a series of irregular cracks, which lie parallel with the lines of fluid inclusions in the quartz.

The augite sometimes shows the effects of mechanical movements in the fracturing and breaking of a grain lying in contact with the granular zone.

The grain shows fracturing throughout, but the'breaking appears 
greatest along the side adjacent to the granular area. As shown in figure 5 , one fragment has been separated slightly from the main portion and small grains of augite lie distributed along the crack. Some of the small grains of augite are very slightly pleochroic, though the main part of the crystal is not.

In specimen 125 (127) the chief constituents are also coarsely crystallized. The microcline has a purplish gray color, and incloses large prisms of augite similar to that previously described, except as to the size of the individuals. The pyroxene in the interstitial areas, however, is without idiomorphic outlines, and occurs mostly in large, irregular grains and aggregates. These are of a lighter green than the idiomorphic individuals in the microcline, and contain a larger number of inclusions of feldspar, titanite and pyrite. This becomes apparent in attempting to select the augite for chemical analysis. The anastomosing granular bands separate the rock into angular lumps of irregular sizes. These bands are not always plainly apparent in the hand specimen, but are revealed with distinctness by the microscope.

In thin section (number 127) the coarsely crystallized feldspar shows a beautiful development of the crosshatching of microcline. The augite and large microcline grains meet each other with tolerably sharp boundaries, though a

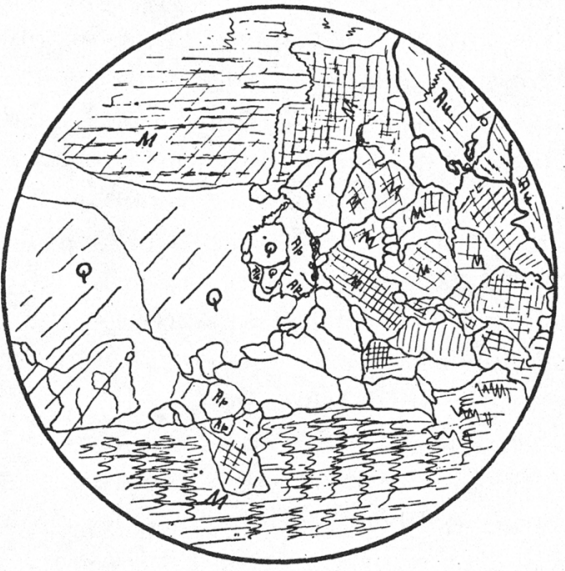

FIGURE 6.-Section showing granular Band intersecting the Rock. small amount of granular micro- microcline.

cline and augite is sometimes observable along the line of contact. There are also narrow bands of granular microcline extending outward from the angle of the augite grain along the spaces between the large grains of microcline. In these zones of granular microcline there occur also small grains of plagioclase. Between the grains of microcline and plagioclase there appears in places, as a cement, a very small amount of feldspar in which fine striations may sometimes be detected.

The microcline is sometimes clouded and contains occasional small plates of biotite, rutile needles, and apatite.

The augite occurs in irregular grains, usually elongated parallel to the vertical axis. It is of a pale green color and nonpleochroic. The prismatic cleavage is well developed. Cleavage parallel to the orthopinacoid 
and clinopinacoid is common, though usually less distinct than the prismatic. Grains in which the cleavage parallel to $\infty P \dot{\infty}(100)$ is well developed, giving a diallage-like appearance, are frequent. 'This is often made more apparent by the presence of thin twinned lamellæ parallel to the same plane. Inclusions of feldspar, sometimes showing the crosshatching of microcline, occur in the augite. Grains of pyrite occur along the cleavage, as also small, irregular flakes of hornblende. The hornblende is green and pleochroic in green and greenish yellow colors.

'The alteration of the augite to compact hornblende was clearly demonstrated by the presence of the latter along the fracture cracks of the former. At one point in the crack there is a small grain of compact green hornblende partially inclosing a grain of iron ore. The hornblende shows well marked parallel cleavage and distinct pleochroism. In addition to this, the irregular fracture lines of the augite are bordered on either side by a thin greenish band, differing from the augite in its double refraction and showing distinct pleochroism. These bands are in direct continuity with hornblende in the larger space and must be regarded, therefore, as the same. The zone of hornblendic substance is often observed. along the fracture lines in the augite and grading into the latter. They are so narrow, however, that, though showing a slight degree of pleochroism, their identity is clearly established only when found in direct connection with larger recognizable masses.

The apatite occurs both in the form of microscopic inclusions in the microline and as rather large rounded grains, both in the microline and in the interstitial areas. These often inclose small grains and prisms with pyramidal terminations, having a lower index of refraction, which are probably quartz. In one of these inclusions the extinction was found to be parallel to the longer axis.

In thin sections of specimen number $126(128)$, which resemblès the. preceding, the granular zones are narrow and consist chiefly of microcline with a very small amount of plagioclase. The large grains of microcline show the characteristic microperthitic intergrowth with albite (?).

The microcline holds as inclusions numerous small biotite plates, apatite, rutile needles, and an abundance of fluid inclusions. The biotite plates are often distributed along the cleavage in parallel lines or bands. In other cases they appear in considerable numbers in prisms and hexagonal sections in intersecting parallel lines corresponding to the cleavage. Dust-like decomposition products appear quite abundant in some areas, and especially along fracture lines.

An aggregate of augite grains, with irregular, but rounded, outline, occupies the space between two large microcline individuals. The augite 
and the coarse feldspar meet each other for the most part in well defined boundaries. In some places, however, a small amount of finely granular microcline occupies the space between them. Rounded grains of calcite, pyrite and microcline areinclosed in the augite. The fracture lines affecting the microcline sometimes extend uninterruptedly through an adjoining augite grain.

Specimen $128(130)$ has a more even and finer grained texture than the preceding, and likewise a more uniform distribution of the constituents.

In thin section the microcline shows a less clearly defined grating structure than in the foregoing, and occurs in irregularly angular and rounded grains from two to five millimeters in diameter, usually separated from each other by a network of finely granular microcline, inclosing here and there larger grains of augite and a small amount of quartz, titanite and calcite, but sometimes meeting each other along a common boundary. The proportion of augite is much less than in most of these rocks. The interstitial granular areas consist of very small grains of microcline and augite, with a small amount of clear, fresh-looking plagioclase feldspar between them in places. The augite does not appear to have suffered much disarrangement of parts, though coarse fractures are common. A small amount of pyroxene occurs in small grains distributed in the granular microcline bands. In one instance a grain lying at the intersection of three granular bands shows a line of fracturing extending diagonally across the parallel cleavage, while narrow zones of hornblende with faint pleochroism border a set of fractures developed transverse to the cleavage. There is a slight difference in extinction and discordance in the direction of the cleavage in the two parts into which the diagonal crack divides the grain. Along this crack there appear small grains of apparently fresh feldspar and one of titanite, together with several small augite grains. A diallage-like appearance due to polysynthetic twinning parallel to the orthopinacoid appears in some grains. No differences were noted between the large idiomorphic augite grains and those appearing in the granular areas. They show little evidence of alteration. More or less quartz is present in the granular areas usually carrying rutile and fluid inclusions and in some cases small rounded granules of augite. Calcite, apatite, titanite and iron pyrites appear in small amounts. The apatite carries small inclusions of quartz.

Specimen 129 (131) resembles the last, except that the microcline has a lighter color, giving the rock a fresher appearance. In general, the texture is medium to coarse, with much larger grains of microcline scattered through the mass. The augite and titanite appear quite uniformly distributed, but on close inspection the former may be observed slightly aggregated in anastomosing lines, giving an obscure net-like aspect. On 
one side the specimen shows a flat surface, along which shearing has taken place.

In thin section in some areas a small amount of granular microcline appears in the spaces between the larger grains. Plagioclase feldspar occurs as small, irregular, unstriped grains in the interspaces and in small amount as a cement. The microcline in general shows greater alteration than in the preceding specimen. Numerous particles of epidote and occasional scales of biotite are scattered through it. Epidote also occurs in connection with the augite.

The augite agrees with that of the preceding specimen. In one case a grain having a pronounced twin lamination parallel to the vertical axis has been much fractured and partially squeezed in two at the middle. The two parts on either side of the major fracture are slightly changed in orientation, while small grains of plagioclase, feldspar and green hornblende occupy the crack. A large grain of apatite inclosed in the augite adjoins the crack. The augite is cut nearly parallel to the clinopinacoid, $\infty P$ io (010), and shows an extinction angle of $43^{\circ}$ for the thicker lamellæ and $33^{\circ}$ for the fine. It is evident, therefore, that the lamellar structure is not due to a fine interlamination of an orthorhombic pyroxene (hypersthene), as might be supposed, but represents a multiple twinning, probably representing gliding planes, due to pressure.

The part of the grain showing greatest fracturing also shows decomposition products in greater abundance. These consist of epidote, calcite, and hornblende; the latter in small pleochroic grains scattered along the fracture lines. In one case, showing only parallel cleavage, the extinction measured upon the cleavage lines was 13 degrees. In some cases an aggregate of small grains of augite have a considerable amount of hornblende in the form of small flakes and grains associated with the augite.

Brown biotite appears in small amount, apparently as a decomposition product.

A mass of rock four feet long, observed on the dump of opening number 11, showed the gradation from the first into the second or ellipsoidal variety.* Specimen $136(139,140)$ was taken about 15 inches from the ellipsoidal end of the block. It consists of coarsely crystallized areas of feldspar and augite, with intervening areas in which the constituents form a moderately fine grained mixture. The augite occurs in large and small grains, the latter in the granular areas. The feldspar (microcline) has a gray color and shows a sharp but variable reflection from the cleavage faces. Twinned individuals having the greatest extent parallel to the twinning plane are common. The augite and titanite both

* This block is representec in the collection by numbers 134, 135, 136 and 137 , taken in consecutive order, the last number being the leopard rock. 
appear in larger grains in the more coarsely crystallized portions. In the finer grained areas the constituents are quite uniformly distributed. In thin section the microcline shows a pronounced development of microperthitic intergrowth with a more strongly doubly refracting, freshlooking feldspar (albite?). In some sections the albite bands show a very fine transverse striation, upon which the extinction is about five degrees. Sometimes small grains of quartz appear inclosed in the albite bands. The inclusions appearing in the microcline occur also in the albite bands and in the quartz and correspond to those already described. In some cases plates of biotite extend across the boundary between the microcline and albite and are partially inclosed in each.

The space between the microcline grains is occupied by finely granular microcline and a striated feldspar, with here and there larger grains of green augite. The striated feldspar is fresher in appearance than the microcline. The laminations are very fine, and according to a number of measurements extinguish at from $4^{\circ}$ to $5^{\circ}$ on either side of the twinning plane where this bisects the angle of extinction of the two lamellæ, thus corresponding to albite or oligoclase. In addition to biotite plates, these plagioclase feldspars often contain large numbers of rounded or nodular inclusions of quartz.*

Specimens 134 (137) and 135 (138), taken from the same block as the above, are much finer grained and contain a considerable amount of quartz, showing with the feldspar a somewhat obscurely banded arrangement. Augite is present in comparatively small amount. The feldspar is pinkish, except in the coarser patches, where it is the usual gray color. Grains of microcline up to the size of peas, sometimes inclosing augite, occur scattered through the finer grained areas. Under the microscope these specimens are seen to differ from the preceding in the greater extent of the interstitial granular areas, the lessened amount of augite, and greater abundance of quartz.

In addition to the microperthitic intergrowth with albite, the larger microcline grains show an abundance of the nodular quartz inclusions, with here and there similar forms made up of an aggregate of albite grains. These nodular quartz inclusions are of considerable size, varying from .035 of a millimeter to .425 of a millimeter in diameter, the larger ones sometimes reaching a length of .95 of a millimeter. The largest individuals are often senarated into a number of parts, each with slightly different extinction. It is noticeable that in many of them the more prominent fractures extend nearly in the same direction. In the granular

*These correspond to the " quartz de corrosion" of the French authors, a term quite inappropriate, as they in no sense represent corrosive action. In correspondence with their peculiarities of shape, the term " nodular quartz" is here adopted for them. 
zones there is an abundance of fresh, finely and sharply striated feldspar usually carrying nodular quartz inclusions.

The quartz occurs distributed through the fine mosaic, often in lines and stringers of elongated grains, in which, in addition to fluid inclusions, the inclusions found in the microcline are abundant.

Epidote appears in particles distributed through the microcline, while the titanite often occurs in association with an opaque iron ore, probably ilmenite.

\section{ELLIPSOIDAL SYENITE-GNEISS OR LEOPARD ROCK.}

The collection embraces specimens showing a gradation from forms in which the constituents are rather coarsely crystallized and the feldspathic cores approximately ellipsoidal through others in which they become more and more elongated, flattened and distorted, accompanied by a decrease in the size of the grains, to those finally in which the constituents are fine grained and arranged in parallel bands. The specimens were taken from the dumps, which offered excellent opportunities for securing an abundance of fresh material.

Specimen $137(141,142,143)$, which was taken from the block furnishing specimens $134,135,136$, represents the ellipsoidal rock in contact with a mass of apatite, the ellipsoids sometimes thrusting themselves in between adjoining masses of apatite which may have belonged originally to the same deposit.

The interior of the feldspathic lumps is sometimes coarse grained and identical with portions of number 136 . They also show a small amount of augite intergrown with the feldspar in these coarse grained parts, while the finer grained, outer peripheral portions show little, if any, augite.

Quartz is present in considerable amount in lines parallel with the longer axis of the lump. In thin section cut transverse to the pyroxene bands they are seen to consist of a fine grained mosaic of feldspar, quartz and augite, while the ellipsoids are composed chiefly of microcline in much larger grains. In some cases, however, the ellipsoid is more or less fine grained throughout and has lines of quartz extending through it parallel with the longer axis of the lump. The augitic bands correspond in structure with the granular belts observed in the coarse syenite. The constituents all show a pronounced tendency toward a laminated arrangement. They consist of microcline and plagioclase in about equal proportions, mostly in small equidimensional grains. Quartz is quite abundant, mostly in elongated grains and aggregates arranged in lines parallel with the lines of augite. They contain as inclusions small plates of biotite and occasionally small rounded grains of augite, unstriped feldspar, and small rhombic sections of titanite. 
The plagioclase is generally fresh, with sharply defined striationa, but in some cases is without stripes and more or less cloudy. It contains an abundance of nodular quartz inclusions. The constituents of the granular areas show a tendency toward the micropoikilitic structure.

The augite occurs in grains and aggregates distributed in a belt along the middle of the granular band. The grains are irregular in outline and often elongated parallel to the vertical axis. The grains usually lie with their long axis approximately parallel with the direction of the band, but in many cases they lie transverse to it. The augite grain is often pleochroic, but without distinct evidences of alteration. It does not differ essentially from that of the coarse grained rock. Pinacoidal and prismatic cleavages are usually well developed in the larger grains.

Apatite occurs sometimes in large elongated grains lying parallel with the general lamination. They carry numerous quartz inclusions, sometimes in short prisms terminated at each end by the pyramid.

A small amount of calcite is present.

In specimen number 142 (147, $148,149)$ the feldspathic lumps are mostly small, usually much elongated, and very irregular in shape. The pyroxene is abundant in the interstitial areas, but is not regularly distributed. In places it occurs in lumps of con-

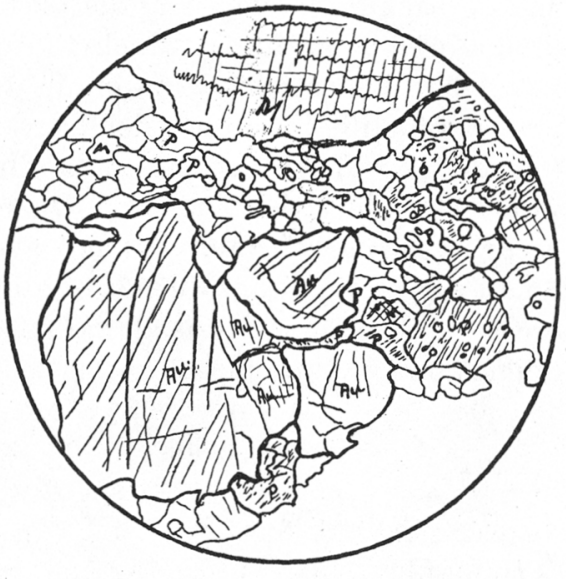

FIGURE 7.-Section transverse to the Pyroxene Band in the ellipsoidal Syenite-gnetss. siderable size, in which there ap- bands and transverse to it.

pear grains of quartz and feldspar and a considerable amount of titanite. The flattened feldspathic lumps arrange themselves somewhat concentrically about these aggregates. The flattened feldspathic masses are relatively small near the central augite aggregate, but increase rapidly in size outward. Often the augite lump represents simply a local thickening of the interstitial band. The augite is of a dark green color and occurs in comparatively large prisms, those of the segregated masses occasionally exhibiting crystallographic outlines. In the interstitial bands the prisms sometimes arrange themselves transversely and project more or less into the feldspathic masses on either side. The feldspathic lumps are made up of a groundmass of fine grained feldspar and quartz inclosing large, often twinned, tabular grains of microcline. 
The size of the large microcline grains is, in general,proportional to that of the feldspathic lump. The titanite occurs chiefly in association with the augite. It appears also in the feldspathic areas, but less frequently.

In thin section the microcline grains of the feldspathic lumps are found to measure from $1 \frac{1}{2}$ millimeters to 2 millimeters in diameter, while the granular matrix in which they lie is composed of grains of microcline and plagioclase varying in size from .3 of a millimeter to .6 of a millimeter.

The small grains of microcline in the granular areas often appear cloudy at the center, while the outer portion is clear and fresh. The same appearance is also observable in some of the plagioclase grains. In these and in many other sections the granular feldspars are often seen to meet each other in straight, sharply defined boundaries, suggesting an approach to crystallographic outlines. This tendency is especially pronounced in grains in which the outer zone is fresher than the interior. The larger microcline grains are filled with particles of epidote, plates of biotite, fluid inclusions, and occasionally microscopic grains of tourmaline. They are generally much fractured and in some cases show cracks filled with calcite. Quartz, calcite and plagioclase feldspar occur in the augite, often, but not always, in connection with fractures. Small aggregates of hornblende needles, accompanied by an opaque iron ore, appear occasionally as alteration products of the augite. The latter often shows distinct pleoch roism:

$\mathfrak{a}=$ greenish yellow.

$\mathfrak{b}=$ green.

$\mathfrak{c}=$ green or slightly yellowish green.

Quartz is not plentiful.

In number $143(150,151,152,153)$ the ellipsoidal masses are larger, but are more or less fiattened and contain a considerable amount of quartz.

Under the microscope the interstitial areas show a pronounced development of the granular or " mörtel structure," in which in some places there appears a preponderance of plagioclase beset with an abundance of nodular quartz, while in others granular microcline predominates.

The constituents have the relations characteristic of the micropoikilitic structure. The larger grains of microcline sometimes show the effects of dynamic agencies in the bending of the lamellæ and undulatory extinction. The augite occurs in irregular grains and aggregates distributed along the middle of the granular band, as usual.

Quartz is quite abundant in angular, often elongated grains. They sometimes inclose small, rounded grains of pyroxene, which in one case appeared to stream out from a large augite grain adjoining.

The apatite occurs, as usual, in rounded and elongated grains, sometimes inclosing rounded grains of augite. 
In specimen $149(161,162)$ the feldspathic ellipsoids are drawn out into irregular, flattened, disk-like forms. The rock shows a tendency to cleave along the face of the augite bands when the breakage is parallel to the longer axes of the disks.

Under the microscope both feldspar and augite are much finer grained than in the preceding. The latter especially appears in smaller and more rounded grains, which lie distributed in a linear direction in the granular feldspathic matrix. The diallage-like structure, due to the presence of twinned lamellæ parallel to the orthopinacoid, appears sometimes in sections cut transverse to the vertical axis. Indications of orographic pressure appear in one instance in the breaking of an augite grain, calcite being deposited in the crack, and, further, in the appearance of fractures extending across adjoining grains of pyroxene. The granular feldspar grains often meet each other in sharp, straight lines. In one case two grains of microcline, one of which is bordered by a small amount of fresh plagioclase feldspar, are separated by a narrow band of the latter, which in polarized light is seen to be twinned, the part on either side of the twinning plane being very nearly, but not quite, in optical orientation with its adjacent microcline grain.

In specimen 138 (144), taken from the dike intersecting the pyroxenite and quartzite, shown on page 101, the feldspathic lumps and interstitial bands are both of a uniformly fine grained granular texture.

In thin section the feldspathic lens-shaped masses are shown to consist of rather fine but relatively uniform grains of microcline, with a moderate amount of quartz and the usual portion of titanite. Occasionally the microcline carries nodular quartz inclusions, but they are few.

In the interstitial zones the constituents are somewhat finer, and the grain lie with their longer axes extended in the same direction. The granular feldspar has the characteristic structure of microcline, while plagioclase is almost altogether wanting. However, these granules carry a considerable amount of nodular quartz.

The augite appears in small grains disseminated in the granular feld. spar matrix. This specimen differs from the preceding in the presence of a considerable amount of hornblende associuted with the augite; sometimes connected with it zonally. Some of the hornblende presents idiomorphic outlines with well developed prism faces meeting at angles of $56^{\circ}$ or $124 .^{\circ}$

\section{STREAKED SYENITE-GNEISS.}

Specimen 140, associated with the last in the exposure described on page 101, shows a nearly complete flattening of the ellipsoids, giving a well developed gneissoid banding. Its identity with the leopard rock, however, is plainly evident from the anastomosing of the augite streaks 
visible on a transverse fracture face. Specimen 156 (186), taken from the dump, represents the same structure in a fresher rock. The constituents appear in a remarkably fresh condition. The feldspathie areas have been completely flattened, so that on a fracture face parallel with the plane of the greatest and least axes of the flattened ellipsoids the constituents are seen in parallel bands. When the rock breaks transverse to this and the augite bands, the latter are seen to coalesce. The mass of the rock is fine grained, with large crystals of microcline scattered here and there along the feldspathic bands.

Under the microscope the rock is seen to consist chiefly of finely granular feldspar, with larger grains of feldspar and augite scattered through

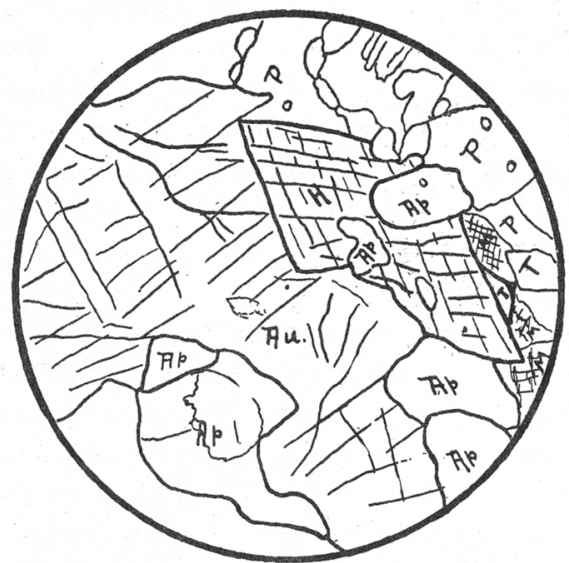

FIGURE 8.-Idiomorphic Hornblende Crystal in the streaked Syenite-gneiss.

$A p=$ apatite; $A u=$ augite $H=$ horublende $T=$ titanite $M=$ microcline. lie scattered along planes in alternation with the bands of feldspar. Hornblende is present in considerable amount, associated with the augite. It does not occur outside of the augite bands. Its relations to the augite, however, are not such as to clearly prove its derivation from that mineral. It sometimes appears in small flakes along the cleavage lines of the augite and is frequently in zonal relation with the latter. It shows the relations with the other constituents characteristic of the micropoikilitic structure, and frequently appears in crystals with characteristic crystallographic outlines.

In figure 8 it is evident that the hornblende is the result of a separate crystallization, as shown by its idiomorphic form and relation to the adjacent minerals. The manner in which it incloses the apatite shows that it has crystallized subsequently to the apatite. Moreover, its per- 
fection of outline indicates that it has not passed through the varied experiences to which the original constituents of the rock may have been subjected. It does not have the crystallographic relations with the augite characteristic of paramorphic development. Titanite also appears here, often in small rhombic crystals.

Specimen 155 (166) shows a pronounced plication of the bands. Along with this the rock shows more or less schistosity in certain directions. The direction of this cleavage, however, has no apparent relation to the direction of the gneissoid banding. The augite streaks are less sharply defined than in the specimen last described (156).

Under the microscope there appears a uniformly very thin, fine grained groundmass of feldspar and quartz, in which large grains of microcline and numerous small grains of augite and hornblende arranged in bands occasionally occur. It is somewhat more granular than the preceding, but in other respects does not show any marked differences.

\section{Character and Relations of the Rocks.}

The relations of these rocks as observed in the field are thus seen to be borne out by their petrographical character. Beginning with the coarsely crystallized rock, in which the gneissic structure is but imperfectly developed, there is a gradation into finer grained and more gneissoid forms, until we have in the last stage a well developed gneiss. In its typical form it consists of a mixture of microcline and augite as essential constituents, while quartz, titanite and pyrite play an accessory role. A peculiar feature of this rock is the large size of the microcline and augite grains and the segregation of both in lumps and patches. The plagioclase feldspar appears in proportion to the extent of the granular areas and constitutes an essential feature of these areas, though usually playing a less important part than the microcline grains. It is usually much fresher than the microcline, but in some cases the opposite is true.

The augite, which occurs in large crystals and grains or segregated masses in the coarse grained rock, also appears in smaller grains as the rock becomes more granular and gneissoid, distributed along the middle of the gneissoid bands.

The constituents of these bands are strictly allotriomorphic in their relations and often show a distinct micropoikilitic structure. These indications of recrystallization become more pronounced in the more gneissic forms. The indications of secondary enlargement of the microcline, and sometimes of plagioclase grains, are also more apparent in these latter specimens. In the coarse grained rock plagioclase feldspar is generally present in small amount as a cement between the grains of microcline. This cement-like arrangement is also apparent to a small 
extent in the more gneissoid variety, but is overshadowed by the general appearance of recrystallization. The idiomorphic character of the augite inclosed in the microcline is wholly absent in all the pyroxene grains appearing in the granular groundmass. These grains often appear prismatic, but never have regular outlines. They frequently lie transverse to the augite band, giving the radiate arrangement already noted.

The evidences of dynamic movements appear in the coarse rock in the fracturing and breaking of the constituents and the presence of cracks extending uninterruptedly across adjoining grains. The last feature was less apparent in the more gneissic rock. The grains of augite usually show an abundance of coarse fractures and occasionally a broken grain with parts slightly disarranged. 'The appearance of breaking occurs in the augite in the granular bands only, and if these bands represent lines of breakage, as is believed, the fracturing of the pyroxene may be correlated with the agencies which initiated the development of the gneissic structure. No distinct evidence of the derivation of the granular pyroxene from the coarse grains and crystals could be made out.

Hornblende does not appear to have been present in the original intrusion. It sometimes appears in a very small amount in connection with the augite, sometimes as an alteration of the latter. In these cases it is destitute of crystallorraphic form. In the gneissic rock, however, the hornblende becomes quite abundant and often presents well marked idiomorphic outlines.

The quartz in the coarse granular rock, as in the case of the feldspar and augite, appears to be distributed in patches. It is apparently more abundant in the more gneissic rock, where the grains assume elongated forms and are arranged more and more in lines.

The laminated gneissic arrangement of the constituents is a marked characteristic of the granular bands. In those of the coarse grained rock it is not marked. It is indicated, however, by the tendency of the quartz grains to become elongated parallel with the band. In the leopard rock there is a distinct lamination of the constituents in the interstitial zone. In cases where the feldspathic lumps are more or less granular throughout, the constituents tend to assume a laminated arrangement, but this is not common.

\section{NOMENCLATURE.}

The characteristics of the streaked gneiss here described correspond to what, according to Zirkel,* may be regarded as a pyroxene-gneiss (augitegneiss). A somewhat similar rock, but apparently containing less augite, has been described by Lacroix as granulitic microcline-gneiss. $\dagger$

* Ijehrbuch der Petrographie, band iii, p. 219.

† Bulletin de la Societé Française de Mineralogie, April, 1889. 
The term pyroxene-gneiss has been applied by the last named author to rocks, of much more basic composition than those under consideration, corresponding to the pyroxenites of the apatite region.

It requires but a brief survey of petrological literature to become aware of a great difference in usage as to the term gneiss. By some authors the mineralogic composition of these rocks is made the basis of definition, and, being regarded as having the greatest analogy with the granites, they are defined as characterized by the presence of feldspar and quartz as essential constituents.*

By many, however, the term is employed in a structural sense to denote the coarser schists, which so often present granitoid characters-a more comprehersive and preferable usage, since the gneissoid or foliated structure may characterize rocks of very diverse composition. The difficulty attending the application of a mineralogical definition is acknowledged by Zirkel when he attempts to draw the line between certain hornblendegneisses and amphibolite. $\dagger$

The mineralogical definition precludes the use of the term syenitegneiss. This name, however, has been used for a quartz-bearing hornblende-gneiss and is given as a synonym for this rock by Geikie. $\$$ Naturally enough Zirkel does not recognize such a division and sets the term aside as misleading. $\S$ On the whole, it seems to the writer that the broader use of the term gneiss in the structural sense is to be preferred. This usage prevails quite generally among the English and French petrographers.

The principles applicable to the classification of the gneisses may be surnmarized as follows :

1. Their mineralogic composition.

2. Identity in composition and texture with the igneous or sedimentary rocks. Origin unknown.

3. Identity in origin, composition and texture with igneous or sedimentary rocks. Under this we have to consider $(a)$ those rocks in which the gneissoid structure is due to dynamic agencies, and $(b)$ those in which it is the result of conditions attending their original solidification.

*Zirkel : "Zum Wesen des eigentlichen Gneisses gehört das jedesmalige Vasein von Kalifeldspath, Quatz und von einem triklinen Kalkaatron feldspath oder Natron-feldspath. . . . Wesentlichen Bestand theile der Gneisses im Allgemeinen bilden aber noch ausserdem Magnesiaglimmer, Kaliglimmer und Hornblende, welche indessen nicht in sammtlichen Gneissen vorkommen, sondern einzeln oder zll zweien auf gewisse Abtheilungen derseben beschränkf sind." (Lehrbuch der Petrographie, band iii, p. 185, 1894.)

† Es ist schwer die Grenze gegen die letzeren (feldspath-quarz haltigen Amphiboliten) zu ziehen, aber nicht wohlgethan, Gestein mit sehr vorwaltender Hornblende zu den Gneissen zu rechnen. Namentlich ist es auch nicht zu billigen gar quarzfreie feldspathaltige Amphibolite diesen Gneissen zuzuzählen. Ferner bedingt der Name Gneiss immerhin ein gewisses planes Parallelgefüge. (Lehrbuch der Petrographie, band iil, p. 215, 1894.)

¥ Text-book of Geology, 3d edition, p, 186.

\& I $\mathrm{t}$ ehrbuch der Petrographie, band iji, p. 215, 1894. 
All of these principles are recognized by petrographers, though usage varies greatly as to their application in the naming of the rocks. Thus, according to some, the specific designation is based upon the prevailing mineral characteristics, while others prefix the names of other rocks with which the gneiss agrees in its textural or mineralogical characters. The latter is the prevailing usage among the Canadian geologists, who apply the term quartzite-gneiss, diorite-gneiss, etcetera, as specific designations to granitoid rocks possessing a parallel structure. Some geologists* restrict the terms syenite-gneiss, diorite-gneiss, gabbro-gneiss, etcetera, to rocks in which there appears a gneissoid structure due to differential movements acting upon the igneous mass in the later stages of its original consolidation.

The desirability of greater uniformity in the method of naming the gneisses is apparent. The following slight modification of methods in quite general use is suggested as a step in this direction:

1. That the term gneiss be used in its broader structural sense for all rocks showing a laminated or banded structure and in which the gneissoid structure is not known to be due to differential movements of the igneous mass before its final consolidation. For the latter a structural qualifying term may be used, as has already been done by Geikie and others, as gneissoid or banded gabbros, etcetera.

2. That where the origin of the rock (whether igneous or sedimentary) is known, the class designations be made to correspond with the character of the original rock. Thus a gneiss kuown to have consolidated originally as a diorite may be termed diorite-gneiss.

3. In those cases where the character of the original rock is unknown, comprising probably the larger part of the group, the extent of knowledge with reference to this point may be indicated by the ending "ic." Thus a rock with gneissic structure and corresponding in its mineralogic composition with the diorites, but whose geological relations are unknown, may be called a dioritic-gneiss.

The following table illustrates these principles as applied to a few of the more important types of rocks : $\dagger$

\begin{tabular}{|c|c|c|}
\hline Analogous massive type. & Of igneous origin. & Origin unknown. \\
\hline $\begin{array}{l}\text { Granite: } \ddagger \\
\text { Biotite-granite. } \\
\text { Hornblende-granite. } \\
\text { Syenite: } \\
\text { Hornblende-syenite. } \\
\text { Mica-syenite. } \\
\text { Pyroxene-syenite. }\end{array}$ & $\begin{array}{l}\text { Granite-gneiss: } \\
\text { Biotite-granite-gneiss. } \\
\text { Hornblende-granite-gneiss. } \\
\text { Syenite-gneiss : } \\
\text { Hornblende-syenite-gneiss. } \\
\text { Mica-syenite-gneiss. } \\
\text { Pyroxene-syenite-gneiss. }\end{array}$ & $\begin{array}{l}\text { Granilic-gneiss : } \\
\text { Biotite-granitic-gneiss, } \\
\text { Hornblende-granitic-gneiss. } \\
\text { Syenitic-gneiss: } \\
\text { Hornbblende-syenitic-gneiss. } \\
\text { Micq-syenitic-gneiss. } \\
\text { Augite-syenitic-gneiss. }\end{array}$ \\
\hline $\begin{array}{l}\text { Diorite: } \\
\quad \text { Mica-diorite. } \\
\text { Gabbro. } \\
\text { Pyroxenite. }\end{array}$ & $\begin{array}{l}\text { Diorite-gneiss : } \\
\text { Mica-diorite-gneiss. } \\
\text { Gabbro-gneiss. } \\
\text { Pyroxenite-gneiss. }\end{array}$ & $\begin{array}{l}\text { Dioritic-gneiss: } \\
\quad \text { Mica-dioritic-gneiss. } \\
\text { Gabbroic-gneiss, or gabbric-gneiss. } \\
\text { Pyroxenitic-gneiss. }\end{array}$ \\
\hline
\end{tabular}

* J. G. Goodchild: 'The Geol, Mag., new ser, Dec. IV, vol. I, number 1, p. 27 (Jan, 1894).

t As types of the sedimentary formations, there may be quartzite-gneisses and quartziticgneirses.

In the absence of a better name, the term "granite" is here used in its restricted petrographic sense. 
In accordance with this view, the classification of the rock under consideration is obvious. It is a gneissoid pyroxene microcline rock, which in some places is almost or wholly free from quartz and corresponds to a pyroxene-syenite, while in others not far distant the increase in the amount of quartz would ally it to the pyroxene-granites. In view of the generally sparing amount of quartz present in the coarse grained forms, they are here referred to generally as pyroxene-syenite-gneiss or simply syenite-gneiss, though it is not to be overlooked that these grade into more quartzose forms, which may be more fittingly regarded as pyroxenegranite-gneisses.

W. G. Ferrier* describes a gneiss from the Château Richer district apparently identical with the "streaked gneisses" described above, to which he applies the name "pyroxene-granite-gneiss."

Lawson $\dagger$ describes a rock from the Rainy Lake region, which he terms hornblende-syenite-gneiss and which he states is not separable geologically from others of the same region which he calls hornblende-granitegneiss. From his description of these rocks it is evident that, except in the ellipsoidal structure and the character of the prevailing ferromagnesian constituent, these rocks show many points of resemblance to the syenite-gneisses of the Du Lievre region. If the view held by Lawson as to the origin of the Rainy Lake rocks is sustained, however, they should be called gneissoid syenites.

\section{Origin of the entipsoidal Structure.}

\section{GENERAL HYPOTHESES.}

Recognizing the intrusive character of the rock, in seeking an explanation of the peculiar ellipsoidal structure two hypotheses suggest themselves:

$A$. That it is primary and represents differentiation of the magma; or,

$B$. That it is secondary and due to dynamic movements subsequent to solidification.

In applying any theory to the phenomena in question we have to consider its competency to explain-

1. The interstitial arrangement of the augite about the ellipsoidal masses;

2. The gradation between this and the segregated lumps and crystals in the coarsely crystallized rock on the one hand, and the parallel arrangement of the streaked gneiss on the other;

3. The presence of the gneissic microstructure and the progressively greater granulation of the constituents as we proceed from the least to the most distinctly gneissoid forms;

* Notes on the microscopical character of some rocks from the counties of Quebec and Montmorency, Canada. Number $14 a$, p. 9 .

† A. C. Lawson: Annual Ropt. Geol. Survey of Canada, 1887-'88, vol. iii, part 1, p. 120 F. 
4. The transverse arrangement of the augite and manner of crystallization of all the constituents of the interstitial granular bands;

5. The concentric arrangement of the lumps and bands about inclosed masses of apatite or pyroxenite;

6. The occurrence of the apatite usually in a more or less crushed condition, but exceptionally in large crystals imbedded in the leopard rock; and

7. The abrupt transition between the different phases in their field relations.

PRIMARY ORIGIN.

Differentiation af the coarse syenite.-If, as seems probable, the coarse feldspathic rock represents very nearly the character of the rock at the time of consolidation from the original magma, it is evident that in places differentiation had proceeded to a considerable extent at the time of crystallization. The crystallization of the pyroxene appears to have been often well advanced before that of the feldspar began. A considerable proportion of the pyroxene, however, occurs in large grains and aggregates in allotriomorphic development with the feldspar. In seeking an explanation of this tendency of the pyroxene to become segregated, two views suggest themselves :

a. That it represents a primary differentiation of the molten magma; or,

$b$. That it is due to the fusion and recrystallization of included fragments of the pyroxenite.

In regard to the first view (a), if this tendency on the part of the constituents toward segregration represents a primary differentiation of the magma, it would seem to accord better with the more generally accepted theory that differentiation has taken place when the magma was quite fluid than with that which supposes it to take place by crystallization, mechanical accumulation and reliquefication. According to Professor Iddings,* a study of the chemical character of rocks shows that the differentiation of molten magmas is not according to stoichrometric proportions, and is therefore not a mineralogic differentiation. As to the method by which concentration has taken place, two views have been expressed: (1) that it is due to molecular diffusion, according to Soret's principle, advocated by Vogt, $\uparrow$ Brögger $\ddagger$ and others; and (2) that it is the result of liquation as advocated by Durocher $\S$ and Bäckstrom. $\|$

If, according to Soret's principle, the differentiation of the magma be regarded as due to differences of temperature, then, in order to explain the lumpy segregation of the coarse grained rock, it may be necessary

*J. P. Iddings : The Origin of Igneous Rocks. Bull. Phil. Soe. Wash., vol. xii, p. 152.

†.J. H. L. Vogt: Geol. Forren, 1, Stockholm Forrhand., vol. 14, May, 1891. p. 476. Reviewed by J. J.

H. Teall in the Geol. Mag, Feb., 1892. Zeitschr. f. prakt. Geol., 1893, p. 272.

$\ddagger$ W. C. Brögger: Zeitsehr f. Kryst. n. Min., Leipzig, vol. 16, 1890.

\& J. Durocher: Ann. des Mines, Paris, vol. 11, 1857, pp. 217-259.

H. B̈̈ckstrom : Jour. Geol, vol. 1, 1893, p. 773. 
to adopt Brögger's suggestion that a partial crystallization of the feldspar set in at the same time that the segregation of the basic ingredients was taking place. Bäckstrom considers* that the formation of basic inclusions by diffusion is improbable, since there can be no difference in temperature between these and the surrounding magma.

The second view $(b)$, that the basic segregations may be due to the recrystallization of fused portions of the pyroxenite, is not improbable, though evidence of this is not at hand. The occurrence of inclosures of the pyroxenite in the syenite-gneiss is frequently observed. These, however, usually retain more or less angular contours and do not appear to have suffered very much from fusion. Professor Lawson has described $\uparrow$ inclosures of hornblende schist in the Laurentian gneiss from the Rainy Lake region, which occur in sharply angular, subangular or somewhat rounded blocks, or as more or less attenuated bands drawn out parallel to the foliation of the gneiss and confused with it. He finds evidence of total or partial fusion and recrystallization to such an extent often as to admit of the deformation of the fragments and their being drawn out into lenses. He thinks that where the magma had higher temperatures the inclosures were entirely absorbed, leaving no trace of their existence except a more basic local facies of the gneiss.

Differentiation of the ellipsoidal rock.-On the assumption of a primary origin it may be held that the distribution of the pyroxene in the ellipsoidal rock represents-

a. A molecular differentiation of the original magma, or

$b$. That it is due to the movement of a partially differentiated magma.

In considering the first view (a) two hypotheses present themselves:

In the first hypothesis (I), which attempts to explain by Soret's principle the peculiar distribution of the basic minerals in the ellipsoidal rock, there arises at the outset great difficulty in conceiving conditions that would give a difference of temperature between the feldspathic lumps and the interstitial pyroxene bands. Moreover, the presence of the gneissic structure would seem to render this view improbable.

In the second hypothesis (II), based on the liquation theory, it may be assumed that there has been a separation of the magma into layers of different composition, and that owing to some disturbance they were broken up and subsequently crystallized in the forms observed. This, however, is considered improbable from the relations of the coarse grained and ellipsoidal varieties and the absence in the former of any indications of differentiation in layers such as the theory might lead one to expect. Moreover, the presence of the gneissic structure seems to preclude any

*Jour. Geol., vol, 1, p. 777 .

†A. C. Lawson : Annual Report Geol. Survey of Canada, 1887-'88, new series, vol. iii, part 1, p. 130 F. 
view which does not take into consideration the movement of the magma during or following its differentiation.

According to the second view (b), the gneissic structure is regarded as the result of the conditions attending the intrusion and consolidation of the igneous magma. Professor Lawson considers* that he has abundant evidence to show that the granite and syenite-gneisses of the Laurentian were plutonic rocks which crystallized slowly from a thickly viscid, tough, hydrothermal magma. Up to the time of its final solidification this magma is supposed to have been subjected to differential pressures, which produced a flow in the mass to which the foliation of the gneiss is ascribed. Geikie and Teall have described $\dagger$ a gabbro in which there appears a banded structure almost identical with that of the Lewisian gneiss. This is regarded as inexplicable, either on the hypothesis of differentiation in situ or on that of successive intrusions, but is thought to have been produced by the deformation of a heterogeneous magma during intrusion.

In applying this view of the development of the gneissic structure to the ellipsoidal rock, two hypotheses are suggested based on the assumptions that may be made as to the character of the differentiation.

If in the first of these, which should be designated hypothesis III, we assume, as in the second hypothesis, a differentiation of the magma by liquation into lumps of feldspathic material separated by thin layers of basic material, then with a gradual movement of the magma it is evident that the forms would be drawn out more and more until the constituents became arranged in parallel bands. It is obvious that on the final solidification of the rock, a structure would result comparable in many respects with that of the leopard rock. As against this explanation, however, we have the following considerations:

1. The apparently cataclastic character of the gneissic structure and crystallization appearing in places. In the coarse grained rock granular bands occur as thin seams, like recemented cracks, separating the rock into coarse grained patches. These seams are sometimes too thin to be readily detected on the surface of the rock, but under the microscope show as narrow, sharply defined bands of granular microcline, fresh plagioclase feldspar and pyroxene inclosing the coarsely crystallized areas of microcline. These granular bands become more pronounced and regular in the ellipsoidal gneiss, where they constitute a well marked band between the feldspathic lumps, with larger grains of pyroxene distributed in a line along the middle of the granular groundmass. In the streaked gneiss the rock becomes granular throughout, though even here quite large grains of microcline often appear in the feldspathic bands.

2. The character of the coarse grained rock and the absence of any indication in it of the kind of differentiation assumed. If a regular lumpy aggregation may

*A. C. Lawson: Ann. Rep't Geol. Survey of Canada, 1887-'88, new series, vol. iii, part 1, p. 139 F. † Sir A. Geikie and J. J. H. Teall : Banded structure of some Tertiary Gabbros in the Isle of Skye. Quart. Jour. Geol. Soc., Nov., 1894, p. 645. 
occur as a result of primary differentiation, then it would frequently characterize intrusive masses, either with or without the presence of a gneissic structure. The absence of observations in support of this is proof presumptive that it does not exist.

3. The relation of the ellipsoids and pyroxene bands to the inclosed apatite crystals and masses. Their concentric arrangement about the apatite indicates that the formation of the apatite antedated the development of the gneissic structure. The difficulties in the way of considering that the formation of the apatite deposits took place in the original magma are:

a. Their large size. The deposits vary from a few inches in cross-section to several feet, and often extend many feet in horizontal and vertical directions. The crystals are frequently several inches in diameter. The larger crystals usually occur in pockets in the pyroxenite, associated with pink calcite, mica, etcetera. A crystal obtained at the Emerald mine, on the Du Lievre, and exhibited at the London Exposition in 1886, measured $62 \frac{1}{2}$ inches in circumference and weighed 550 pounds.* Crystals one to two inches in diameter frequently occur in the granular deposits. In pit number 11 at High Rock, a crystal five or six inches in diameter was observed in an inaccessible part of the wall imbedded in the ellipsoidal rock.

b. Their inclusions. Doctor Hunt noted rounded crystals of quartz and carbonate of lime as inclusions in the apatite. $\dagger$ Similar observations were made by Emmons, $\ddagger$ while Harrington states $\&$ that the apatite crystals frequently inclose calcite, pyroxene, phlogopite, zircon, sphene, fluorspar and pyrite. While it cannot be positively asserted that these inclusions characterize the crystals imbedded in the ellipsoidal rock, the correspondence between these crystals and the other deposits as to their occurrence favors the supposition that they had

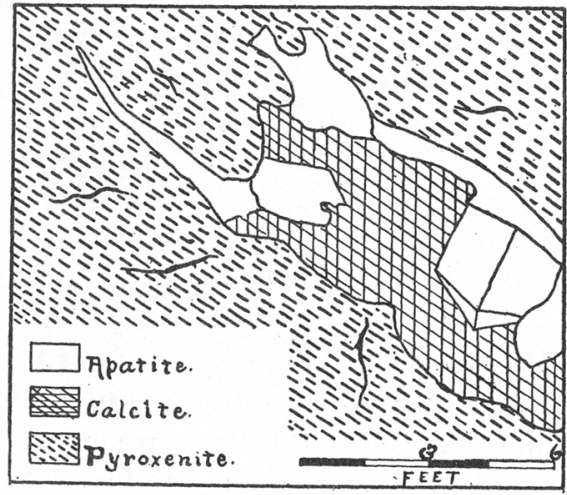

FIGURE 9.-Pocket in the Pyroxenite filled with Apatite and Calcite. (After Harrington.)

A large crystal of apatite projects from the side of the cavity. a similar origin.

c. The rounded outlines of the apatite crystals. This feature of the apatite crystals of the Laurentian veinstones was regarded by Emmons $\|$ as due to partial fusion, while Hunt If considered them to be the result of the solvent action of the heated watery solutions from which they were supposed to have been deposited. The appearance of rounded angles on crystals found in cavities in the pyroxenite seems to favor the latter view.

\footnotetext{
* Descriptive Catalogue of the Economic Minerals of Canada, London, 1886.

$\dagger$ '. J. Hunt: Geology of Canada, 1866, p. 203.

$\ddagger$ E. Emmons: Geology of the First District of New York, p. 57.

\&B. J. Harrington: Geol. Survey of Canada, 1877-'78, report G, p. 15.

\| E. Emmons: Geology of the First District of New York, pp، 57, 58.

IT T. J. Hunt: Chemical and Geological Essays (1891), p. 213.
}

XVIII-Bull. Geol. Soc. Am., Vol. 7, 1895. 
d. The crushed condition of the apatite. The smaller deposits are generally more or less reduced to a granular condition. Often the peripheral portion is granular, while the interior consists of coarse grains and fragments of crystals, with fine granular apatite filling the interstices.

Hypothesis IV assumes that the heterogeneous character of the magma was due to the fusion of inclosed fragments of the pyroxenite and, owing to the differential movement of the mass, the absorbed material became distributed in the magma and crystallized in the form observed.

The presence of inclosures of pyroxenite in the syenite-gneiss has been referred to. In specimen 140 a somewhat rounded, subangular mass of pyroxenite appears in contact with the ellipsoidal gneiss. In some places the line of contact is well defined, but in others it is not. Under the microscope, however, the boundary is quite sharp and marked on the pyroxenite side by an abundance of scapolite (wernerite), while no'trace of this mineral appears in the ellipsoidal areas. However, the pyroxene bands of the latter, which are cut off by the line of contact, are much more prominent adjoining the pyroxenite, gradually diminishing in thickness away from the boundary. Another instance is seen in specimen 153, not elsewhere described. In this there appears an irregular fragment of pyroxenite inclosed in the ellipsoidal rock. The structure of the latter is somewhat obscure. The pyroxene appears more abundant in the vicinity of the inclosure. Indications of orographic agencies subsequent to the development of the ellipsoidal structure appear in the schistosity of the rock and the presence of narrow bands of feldspathic material and rather large plates of biotite, which extend continuously across both the ellipsoidal rock and the pyroxenite. According to this hypothesis the apatite may be considered to have been derived from the pyroxenite and become more or less crushed and drawn out before the rock became wholly solidified. This hypothesis appears to be sustained by a number of considerations. The greater abundance of pyroxene in the vicinity of the inclosed masses of pyroxenite seems to indicate a partial absorption of the latter. The occurrence of interstitial pyroxene in greater abundance in certain areas in the ellipsoidal gneiss may indicate the position of smaller inclosures which have been entirely absorbed. Moreover, the character and condition of the apatite inclosures seem to favor this view. On the other hand, however, difficulties are encountered when we attempt to explain by this process-

The shell-like distribution of the absorbed pyroxenic material prior to solidification, and

The apparent cataclastic character of the gneissic structure.

That a more or less completely banded structure may be produced in 
this way, as claimed by Lawson,* is probably true, but whether the basic material may be so distributed as to crystallize out in the form shown in the ellipsoidal gneiss is doubtful.

While the argument drawn from the character of the gneissic structure is not beyond question, it is strongly presumptive against the primary origin of the ellipsoidal structure.

\section{SECONDARY ORIGIN.}

In attempting to explain the ellipsoidal structure by appealing to dynamic processes (hypothesis V), it is necessary to consider (1) the character of the original rock and (2) the agencies and their mode of operation.

The character of the original rock, as inferred from the coarse grained variety, was evidently peculiar. Its heterogeneous character is indicated by the tendency of the feldspar, pyroxene and quartz to appear in large grains, lumps and segregations. In some cases, however, the rock has an even, granular structure and consists of feldspar and pyroxene quite uniformly distributed. In places the rock is mostly coarse feldspar, with scattering grains and small aggregates of pyroxene. In other places the pyroxene occurs in much greater amount, both as crystals of various sizes and aggregates of grains, apparently constituting from 15 to 20 per cent of the rock. In general the irregular pyroxene aggregates vary from the size of millet seeds up to marbles, rarely larger. They usually inclose more or less feldspar in small grains; also pyrite and titanite. In areas showing a large amount of pyroxene the latter sometimes appears in idiomorphic grains, of large size, inclosed in the microcline. They also appear at times in the quartz areas. In the specimens showing a uniform distribution of feldspar and pyroxene, idiomorphic forms of the latter were not seen.

While the arrangement and mode of crystallization of the constituents seem to indicate partial differentiation of the original magma, it is not improbable that some of the pyroxene was derived from the inclosures of the pyroxenites, as already suggested.

The agencies which may be appealed to as effecting the changes observed are those usually classed under the head of dynamic metamorphism. These may be conceived to have effected the crushing of the coarse grained syenite, accompanied by solution, recrystallization and rearrangement of the constituents under the influence of water, and probably also of heat. The variation in the extent of the structural alteration may be due to the different attitudes of the inclosing rocks. It will scarcely be denied that certain portions of the intrusive mass

\footnotetext{
* A. C. Lawson: Ann. Rep't Geol. Survey of Canada, 1887-'88, new series, vol, iil, part 1, p. 134 F.
} 
would be called upon to sustain a much greater pressure than others, while some parts might escape almost wholly. With the breaking of the rock under the influence of strain there would be more or less pulverization of the minerals along the sides of the crack. This would favor the chemical action of percolating waters. With the recrystallization of the constituents taken into solution the crack would become healed. This may be conceived as taking place (1) by partial solution of the powder, with a secondary enlargement of the remaining portions ; or (2) by complete solution and recrystallization of the pulverized material. In either case the filling would be fine grained, since even if wholly recrystallized the process would probably go on synchronously with the movement of the rock. Evidence that this process has taken place at a later date is sometimes seen in the presence of healed cracks cutting across the banding.

With increasing pressure the rock may be reduced to a coarsely fragmental condition, and if the process were stopped at this stage the result would probably be a mass of irregular fragments, cemented together by fine grained interstitial material. The pyroxene within reach of the percolating waters would be dissolved to a greater or less extent, and on subsequent recrystallization would appear in grains marking the spaces occupied by the solutions. The relative solubility of pyroxene and feldspar under the conditions here postulated is unknown. The relative effects of weathering, however, are well shown by the manner in which the pyroxene decays on exposed surfaces of the ellipsoidal rock, leaving sharp trenches surrounding the feldspathic portions. Since basic minerals melt at somewhat lower temperature than the acidic, it may be supposed that the temperature of the rock became sufficiently great to melt the pyroxene, but not the feldspar.* While the convoluted forms assumed by the ellipsoids are suggestive of plasticity, it is scarcely probable that the heat has ever reached the point indicated. This is inferred (1) from the occurrence occasiona'ly of crystals of augite, which are apparently original, inclosed in grains of microcline in the ellipsoidal areas; and (2) from the consideration that if the heat is due to the shearing movement of the rock, as generally conceived, it must be generated slowly, and hence would probably be dissipated nearly, if not quite, as rapidly as it is produced.

As the ellipsoids became more and more flattened the interstitial pyroxene bands would assume a parallel arrangement, as in the case of other similar gneissoid structures. $\dagger$

In support of the hypothesis of dynamic origin we note:

* J. G. Goodchild: Geol. Mag., new series, Dec. IV, vol. 1, no. 1, Jan., 1894, p. 23. †F. Zirkel : Lehrbuch der Petrographie, band iii, p. 205. 
1. The gneissic character of the microstructure as traced from the coarse grained through the ellipsoidal to the streaked varieties. The augen-structure represented in specimen number 160 is clearly typical of the results usually oredited to dynamic movements. Inasmuch as this appears to be merely a speciul development of a portion of the rock having little or no augite, it would not seem unwarranted to infer that the agencies operating here affected other portions of the rock as well, and hence that the development of the gneissic structure was in both cases referable to the same agencies.

2. The evidence of recrystallization of the granular areas. This appears not only in the irregular interlocking outline of adjacent grains, but the frequent presence of fresh plagioclase feldspar as a cement for the other constituents and the development of hornblende in idiomorphic forms in the more gneissoid rock.

3. The indication of dynamic action as shown ( $a$ ) by the fracturing of the augite and microcline grains, and $(b)$ the indication of strain appearing in the bending of the microcline lamellæ, accompanied by undulatory extinction and the development of polysynthetic twinning of the pyroxene. These phenomena are chiefly confined to the coarse grained rock, and even here are not pronounced. It may be that some of them are due to movements subsequent to the development of the gneissic structure. The appearance of strain in the microcline, however, in certain cases (page 116) seems rather to be connected with the production of the gneissic structure. This is true also in certain cases in the breaking of the pyroxene grains, but in general neither pyroxene nor microcline furnish any evidence as to what proportion, if any, of the granular materials represent fragments of the original minerals.

4. The character and relations of the inclosed apatite. The significance of these deposits lies in their generally crushed condition. The crushed appearance of the apatite is more pronounced, so far as the limited data at hand shows, in the deposits occurring in the streaked gneiss than in those in the coarser rock. In places where the gneissic structure of the rock is imperfectly developed, the crushing of the apatite likewise appears incomplete. The mass is made up of rather coarse fragments, with granular apatite filling the interstices. In some cases (page 107) the mass is intersected by thin seams of feldspathic material extending in from the walls and continuous with the surrounding layer. Often the deposit is reduced almost wholly to a granular condition. These granular deposits, called sugar apatite, are sometimes of considerable extent, as noted by Professors Penrose* and Harrington. $f$

Professor Penrose says: "The granular variety known as sugar apatite is of a white or pale green color and looks like coarse sand, more or less coherent. * * * It is one of the purest forms of apatite mined. It is uncertain what could have caused the apatite to assume this granular condition."

Professor Harrington states that "though at some localities the apatite occurs chiefly in crystals, at others it is wholly or almost altogether massive, varying from compact or crypto-crystalline to coarse granular. Frequently also it exhibits a distinct lamellar texture. A friable saccharoidal variety is very common and often termed 'sugar phosphate.' When white it is sometimes difficult to distinguish by the eye from some forms of quartz sandstone. * * * Crystals are sometimes imbedded in this granular apatite, and frequently also rounded masses of apatite

* R. A. F. Penrose: Bull. 46, U. S. Geol. Surv., p. 38.

† B. J. Harrington: Geol. Survey of Canada, p. 14 G. 
up to many inches in diameter. Similar masses of pyroxene as well as crystals are also sometimes imbedded in the apatite."

It is also worthy of note that the form of the deposits in both gneiss and pyroxenite is strongly suggestive of crushing and squeezing. This was remarked by Harrington,* who says: "The apatite masses look as if they had been driven or squeezed into the curious forms which they now present during the folding or crumpling of the enclosing rock."

The explanation of the large apatite crystal (pages 103,127) in the leopard rock is not without difficulty. One or two instances only were observed and we have no information that they ever occur in the streaked gneiss. From the manner in which the ellipsoids and bands of the gneiss arrange themselves concentrically about the apatite, it is clear that the crystallization of the apatite took place prior to the development of the gneissic structure.

Four views may be suggested to account for the apatite crystal in its present position :

1. That it crystallized out of the original magma before the solidification of the latter. From the relations of both the crystallized and granular deposits of apatite occurring in the syenite-gneiss, it is evident that an explanation that will account for the presence of one must apply also to the other. We have considered already the objections to the view of the formation of these deposits in the original magma (page 127). These are the large size of the crystals, their inclusions and rounded outlines, and the extent and more or less crushed condition of the deposits.

2. That it is due to segregation and crystallization after the solidification of the rock. The belief is expressed by Harrington in the report above cited that in many cases there has been a segregation of apatite and other minerals which accompany it from the surrounding rock into irregular or lenticular masses without any true cavity or crevice having ever existed. The growth of crystals by replacement in situ has been noted by various observers. $\dagger$

Indications of such development appear in the small hornblende crystals occurring in the streaked gneiss, as described in another part of this paper (page 118). The development of large crystals by this process, however, has not been demonstrated and is considered improbable.

3. The third view is that they were deposited in a cavity in the syenite prior to the development of the gneissic structure. The objection to this hypothesis lies in the difficulty of accounting for the obliteration of the cavity without crushing the apatite. It may be supposed that the cavity was large in proportion to the size of the crystal and did not become closed at once but gradually, and that by the time the walls had closed in, the surrounding rock had become sufficiently plastic to adjust itself about the crystal without breaking it. The objections to the view that the rock had reached such a condition of plasticity have been considered (page 130). Moreover, the former presence of a cavity should be indicated by an irregularity in the arrangement of the ellipsoids about the apatite, which does not appear to be the case, though the observations upon this point were not conclusive. 
4. The fourth view, and probably the correct one, is that the apatite was formed in cavities in the pyroxenite, and that it became inclosed in the syenite during the intrusion of the latter. The objection to this view, as in the preceding, lies in the difficulty of accounting for the preservation of its crystallographic form. However, as the ellipsoidal rock evidently represents an early stage in the development of the gneissic structure, it is probable that the differential movement at this point was not so great but that the crystal was able to withstand the strain.

\section{SIMILAR STRUCTURES IN OTHER ROCKS.}

Analogous structures in mica-gneisses are well known. A variety called stengeliger-gneiss (wood-gneiss), according to Zirkel, $*$ is characterized in some cases by bands of mica winding about the stalk-shaped or wreathshaped feldspar-quartz masses, so that these are inclosed on all sides by the mica layers. On cross-fracture, therefore, these will show discoidal, ellipsoidal, elongated, roundish, trapezoidal figures formed by the mica bands. Up to this point the description applies very well to the Ottawa occurrences, except in the character of the mineral forming the bands. Beyond this, however, the analogy fails, as further alteration produces an asbestos-like structure which has no counterpart in the rocks under consideration.

Rothpletz has noted $\nmid$ a structure analogous to that here described in the greenstone-schists (actinolite-schists) of Hainchen, and Williams $\ddagger$ from northern Michigan. Both of these observers ascribe it to brecciation in situ, while the former explains the rounded character of the fragments and the production of much of the interstitial material by the rubbing torgether under the action of much orographic pressure of a mass already finely subdivided by cracks. Lawson has described similar occurrences in the Lake of the Woods region. $\S$

\section{ConCLUSION.}

Reviewing now the different hypotheses in the light of all the evidence available, it is apparent that no one of them seems to offer a full and adequate explanation. The ellipsoidal and the gneissic structure in these rocks are clearly closely related in origin, and any conclusion affecting the one has a direct bearing upon the other. Our knowledge of the processes by which the ancient gneisses were formed is extremely limited. That they may be formed by dynamic processes has long been recognized, and it is now well established that a laminated structure comparable to that of the gneisses may be produced in deep-seated igneous

* Lehrbuch der Petrographie, band iii, p. 203.

$\dagger$ Zeitschrift der deutsch geology Gesell., vol. 31, pl. ix, $x_{1}$ 1879, pp. 374-397.

$\ddagger$ Bull, 62, U. 8. Geol. Survey, 1890, pp. 166-177.

8.Geol, and Nat. Hist. Survey of Canada, Ann. Rep., 1885, Rep. CC, p. 51. 
rocks as the result of the conditions attending their intrusion. In consequence of the constitutional changes which appear to take place in rocks when subjeeted to great orographic pressure, it becomes in many cases extremely difficult, if not impossible, to distinguish between the two kinds of gneisses. Moreover, our knowledge of the cause of differentiation of igneous magmas is as yet little more than a speculation, but that the nature of this original differentiation conditions in part the character of the structure resulting from subsequent processes is obvious.

While in many respects incomplete, involving, as it does, much that is as yet little understood in the metamorphism of rocks, on the whole the evidence seems to favor the last hypothesis (V), namely, that of dynamic metamorphism.

Briefly summarized, this hypothesis supposes-

1. That the structure characterizing the leopard rock is due to orographic agencies and represents an intermediate stage in the development of a streaked augitesyenite-gneiss out of an augite-syenite which was distinguished by a coarsely crystallized structure and by a somewhat irregular aggregation of pyroxene. The character of the original magma may have been modified somewhat by the absorption of included fragments of pyroxenite.

2. That the distribution of the pyroxene has been effected presumably by the solution of portions of the original constituents and their recrystallization along lines marking the location of the cracks.

3. That with continued pressure these lumps have been more and more drawn out, the process being accompanied by recrystallization until the rock assumes the streaked gneissoid form.

While in general the evidence of crushing is rendered more or less doubtful by the extent of recrystallization, in one case (number 159) it is undoubted. This represents a partly developed gneiss in which, however, the ellipsoidal structure is but imperfectly presented. Though differing considerably from the rest of the rock in general appearance, there is little doubt but that it belongs to the same mass. The groundmass is much finer than in any of the others and shows much less the effects of recrystallization. Large grains of microcline are partly crushed and drawn out into lens-like forms comparable to the augen-structure. A significant feature is the arrangement of the augite in irregular bands about the feldspar and quartz. In some of the augite grains the appearance of crushing and dragging is pronounced, while the general appearance of the rock, both in hand specimens and under the microscope, admits of no other conclusion than that its present structure is due to the effects of orographic pressure. 